\title{
Causes Of Women Harassment At Workplace
}

\author{
Rana Saba Sultan \\ Department of Sociology \\ University of Karachi \\ Ambreen Akbar \\ Department of Media Communication \\ Sindh Madarsa-tul-Islam University, Karachi \\ Nargis Ahmed \\ Department of Sociology \\ Jinnah University for Women \\ Mussarat Parveen \\ Department of Sociology \\ University of Karachi
}

\begin{abstract}
The purpose of this study was to evaluate the causes of women harassment at work place. Pharmaceutical and Garment factories S.I.T.E, Karachi are used to analyze the subject. This study elaborates different types and forms of harassments and explains the laws, legal constitutional framework and few court judgments on sexual harassment as a reference. The researcher comprises of comprehensive reviews of the past research studies. A concrete research review has been done in order to cover all the corners of the subject. Then explains the research methodology in which the study drives the research method to the topic. Structured questionnaire was designed to extract the information about the respondents and analyze it through research techniques. 300 total number of female respondents were taken from 10 different pharmaceutical and garment factories of S.I.T.E Karachi. Descriptive and inferential research method was applied to understand the depth of the topic. A regression analysis was used to find the relationship between dependent and independent variables.
\end{abstract}

Key Words: Workplace, Women, Harassment, Causes, Rules \& Regulations

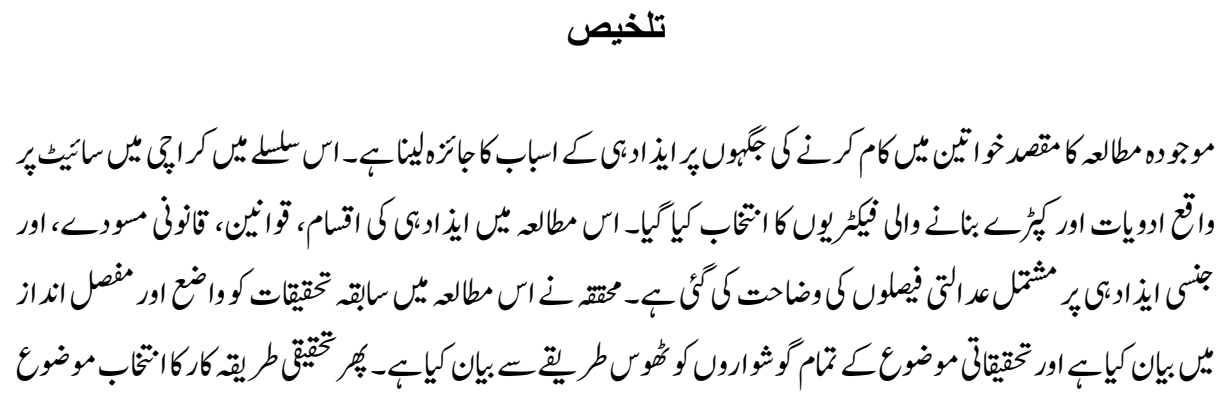




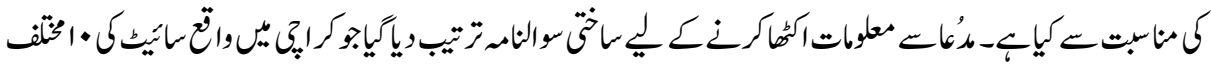

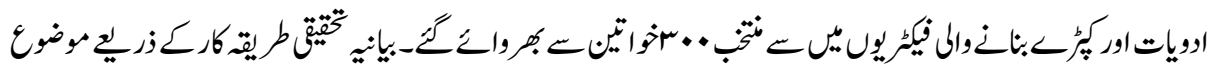

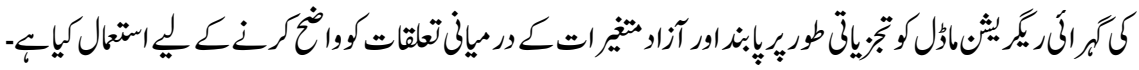

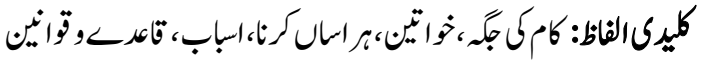

\section{Introduction}

The working women face a lot of problems in society where it is believed that they must avoid all contacts with men unrelated to them. Due to this, most assume that working women do not possess a good moral character. Even though much has changed in the last decade, still even in urban areas, when a woman steps out of the house for work, she must be mentally prepared for stares, rude remarks from strangers, and other different kinds of harassments. The conduct must first be unwelcoming and offensive to the employee then that employee must object to such behaviors' giving a chance to employer to correct the conduct. Lastly, the conduct must be of such a serious nature that it makes a marked adverse impect on the victims' ability to perform his/her duties efficiently and effectively. Workplace harassment can be committed by: Worker, co-worker, an employer, group of co-workers, customer or client, Public member (Federal Communications Commission Staff, 2011). It is a fact that most of the cases of women harassment in Pakistan remain unreported considering the male-dominated society that often questions victim's innocence and integrity than the offender.

\section{Types of Harassment}

Harassment comes in many types, which are discussed below:

\section{Verbal Harassment}

Verbal harassment refers to an abusive behavior that includes hateful speeches or comments that are related to sex, race, religion, cast, origin or creed. In a verbal abuse, inapt words are used to hurt or humiliate another person.

\section{Bullying}

Bullying is a complex phenomenon of unwanted, offensive and malicious behavior which undermines an individual through persistent negative attacks. There is typically a very rational abuse of position or power that can manifest itself in physical, verbal or nonverbal forms. 


\section{Sexual Harassment}

Sexual assault may be physical, ranging from unwanted touching, rape, to any kind of indecent assault. Sexual harassment mostly carries with it threats of employment reprisals if such advances are refused. Sexual harassment has been defined by the federal government and courts as "illegal employment discrimination" (Barron's Business Dictionary). In Sexual Harassment include: Unnecessary and unwelcomed touching, Request for sex, Sex related talks and jokes, Intimidating behaviors such as demanding sex in return for promotions at workplaces, Sexually explicit pictures, Sexually explicit physical contact, Sexually explicit emails or messages, Intrusive questions about a person's bodily parts.

\section{Racial Harassment}

Racial harassment can be defined as hostility towards people on the basis of their race, national or ethnic origin.

\section{Causes of Women Harassment at Workplace}

Harassing behavior is a result of biological urges. Which include the natural and mutual attraction between male and female, a stronger male sex drive, and men in the role of sexual initiator? Following are the most important causes of women harassment at work place.

1. Sexual harassment is a result of aspect of the workplace infrastructure that provides opportunities for harassment. It is the individuals in position of little power, either men or women, who are most likely to be the targets of harassing behavior.

2. Sexual harassment caused by a number of organizational problems, including the inequalities of power and status within the organization, which increases the likelihood of sexual harassment.

3. Sexual harassment is the extension of male dominance that thrives in the larger society.

4. Sexual harassment is a manifestation of male power.

5. Motivation is a great cause of harassment.Physical attractiveness of victims may be the motivating force for harassment. Certain male workers would thus be tempted to establish social or sexual relationships with their female co-workers, or give unwanted sexual attention.

6. In the working environment many external factors contributes towards sexual harassment in the workplace.

7. Female employees sat lower positions, with less power and authority are mostly made target of sexual harassment by those above them.

8. Private environment with confined work space where women are harassed more than those are that work in open workspace.

9. An unprofessional climate contributes more towards women harassment then a professional environment. (The University of British Columbia) 


\section{Harassment Bill of Pakistan}

President Asif Ali Zardari signed the "Protection against Harassment of Women at Workplace Bill 2010", which was aimed at providing a safe working environment. $\mathrm{Mr}$ Zardari reiterated the commitment of the government to ensure equal rights for men and women in accordance with the Constitution. The bill is aimed at creating a working environment for women which is free of harassment, abuse and intimidation. On Jan 21, the National Assembly unanimously passed the bill and the Senate on Feb 26. Shahnaz Wazir Ali, who was adviser to the Prime Minister on subject of Social Welfare, recalled the process of drafting the legislation. The Alliance against Sexual Harassment (Aasha) has called the signing of the bill a milestone for women. Punishment for such actions will range from a censure to dismissal to fine under the law which is unspecified. The law defines harassment as "any unwelcome sexual advance, request for sexual favors or other verbal and written communication or physical conduct of a sexual nature or sexually demeaning attitudes, causing interference with the work performance or creating an intimidating, hostile or offensive work environment, or the attempt to punish the complainant for refusal to comply to such a request or is made condition for employment" Dawn Newspaper. (2010, December 21).

\section{Literature Review}

The biological models of women harassment suggest that sexual behavior is simply a natural extension of human sexuality. Its assumptions include a natural, mutual attraction between men and women, a stronger male sex drive, and men in the role of sexual initiators (Tangri et.al, 1982). The Evolutionary Adaptation Modelis explicated by Studd and Gattiker (1991) who presented the proposition that because reproduction entails different cause/benefit calculi for women and men, there are different reproductive strategies and psychological mechanisms to support them. Specifically, men should aggressively compete for access to sexually receptive women of reproductive age, establish long term mate ship, in which confidence of paternity is maximized and expand parental investment to increase the success of offspring produced. Tangri et al (1982) were the first to suggest in "Organizational Model of women harassment" that sexual harassment is a result of aspects of the workplace infrastructure, which provide opportunities for harassment. According to them, powerful women may harass subordinate men, and such occurrences are rare to find only because women are generally employed in sub-ordinate positions (Gutek \& Morasch, 1982). Sex role spill over is defined as the Carryover into workplace of gender based expectations for behavior that is irrelevant or inappropriate to work. Workplace dispute resolution model gives a sociological perspective on sexual harassment (Opotow, 1990). Thus, Vaux (1993) see sexual harassment as: "An instance of Moral exclusion, whereby members of a relatively powerful group conduct their lives in their own interest, sometimes at the expense of a 
relatively less powerful group, in such a way that any harm is denied, diminished or justified (Lach, \& Gwartney,1993).

The Illinois model Hurt (2000) posits that the experience of sexual harassment is a workplace stress, whose antecedents and outcomes are to be explored with organizational and its environmental context, as other organizational stressor Fitzgerald et.al., (1995) the four-factor model developed by Hausen M. (1998) to identify the risk factors of sexual harassment. Such a multifaceted approach is necessary in view of the socio-cultural differences among the three main ethnic groups - Malays, Chinese, Indians/others - of Malaysian workers. For example, certain forms of sexual behavior may be considered harassment by one group, but non-offensive by another less conservative group. Women harassment may also depend upon her dressing style. Moreover, factors such as, sex ratios, availability of workspace and sexist attitudes, which constitute the working environment of an organization, also have a strong impact on the rate of occurrences of sexual harassment in a particular workspace.

\section{Objectives of the Study}

1. To explore the relationship between the demographic characteristics of women and types of harassment.

2. To identify the relationship between the organizational environment and types of harassment.

3. To find out the relationship between motivational factors and types of harassment.

4. To find out the relationship between women's position and types of harassment.

5. To explore the short and long term effects and types of harassment.

\section{Hypotheses}

1. Types of harassment are likely to be related with the age of women employee.

2. Types of harassment is likely to be related with the Educational qualification of women employee.

3. Types of harassment are likely to be related with the marital status of the women employee.

4. Types of harassment are likely to be related with the motivational factors of the women employee.

5. Types of harassment are likely to be related with working environments of an organization.

6. Types of harassment are likely to be related with the position of women employee. 


\section{Research Methodology}

The present study is an Exploratory Research, which comprises of four main segments to drive methodology for analyzing sexual harassment at work place. The four segments are: (1) Interview Schedule (2) Sampling. (3) The data collection from the proposed research methodology and information. (4) Statistical analysis of data. The universe of present study is textile factories and pharmaceutical Companies of Sindh Industrial \& Trade State which is known as S.I.T.E, Town Karachi. SITE town, is a less densely populated western part of Karachi, this area is located in the heart of the city and designated as an Industrial Area in 1963. The researcher used stratified sampling method, 300 respondents were drawn adopting the procedure of proportional allocation. The respondents were randomly selected from 08 textile factories and 02 pharmaceutical companies because female workers participation is very high in these sectors. It was decided to draw a stratified random sample of $(n=300)$ respondents, which would consist of $n 1$ (LAKHANI TEXTILE), n2 (DALAL INDUSTRIES), n3 (FORTUNE BUSINESS INTERNATIONAL), n4 (RELIANCE INDUSTRIES), n5 (NEHA GARMENTS), n6 (PAK DENIM MILLS, PVT.LTD), n7 (MECTOR PVT LTD), n8 (GARMENTS TRADING), n9 (LIBERTY TEXTILE MILLS), n10 (GLEXO WELCOME).

$N=n 1+n 2+n 3+n 4+n 5+n 6+n 7+n 8+n 9+n 10=300$

Table \# 1 shows the proportionate allocation of sample size.

Table: 1

Frequency and percentage distribution according to the universe and sample size

\begin{tabular}{|l|l|c|c|c|}
\hline & \multicolumn{1}{|c|}{ Name of organization } & $\begin{array}{c}\text { No. of female } \\
\text { employees }\end{array}$ & Percentage & $\begin{array}{c}\text { Sample } \\
\text { size }\end{array}$ \\
\hline $\mathrm{n} 1$ & 1. Lakhany Extile International & 456 & $(15.6 \%)$ & 47 \\
\hline $\mathrm{n} 2$ & 2. Dalal Industries (Pvt) Ltd & 230 & $(7.9 \%)$ & 24 \\
\hline $\mathrm{n} 3$ & 3. Fortune Usiness International & 150 & $(5.1 \%)$ & 15 \\
\hline $\mathrm{n} 4$ & 4. Reliance Industries & 239 & $(8.2 \%)$ & 25 \\
\hline $\mathrm{n} 5$ & 5. Neha Garments & 258 & $(8.9 \%)$ & 27 \\
\hline $\mathrm{n} 6$ & 6. Pak Denim Mills Pvt Ltd & 351 & $(12.1 \%)$ & 36 \\
\hline $\mathrm{n} 7$ & 7. Mector Pvt Ltd & 344 & $(11.8 \%)$ & 35 \\
\hline $\mathrm{n} 8$ & 8. Garments Tradeing & 209 & $(7.2 \%)$ & 21 \\
\hline $\mathrm{n} 9$ & 9. Liberty Textile Mills & 394 & $(13.5 \%)$ & 41 \\
\hline $\mathrm{n} 10$ & 10. Glexo Welome & 279 & $(9.6 \%)$ & 29 \\
\hline & Total & $\mathbf{2 9 1 0}$ & & $\mathbf{3 0 0}$ \\
\hline
\end{tabular}




\section{Method of Data Collection}

In the present study, the interview schedule method was used for data collection which consisted of 48 questions. The study of the women harassment at workplace in accordance with the selected factories and codes, a member of the factories were informed due to legal access but respondents were not approached through their factory`s channel. In order to make sure the strength of the data, the total numbers of 300 respondents were selected. Most of the questions were close-ended according to need, but few were open-ended.

\section{Statistical Method of Analysis}

In the present study, simple tables were made representing each question and percentages were drawn. In order to test the validity of hypothesis various statistical inference are made by which the significance of the variables is ascertained. Many statistical methods of testing are generally used for the purpose, such as linear regression and ANOVAs tests. On the basis of these tests the null hypothesis are ultimately accepted or rejected, and if the null hypothesis is rejected then the pattern of association can be determined by the coefficient sign in models. The study uses linear regression analysis to find out the relationship between dependent and independent variables.

\section{Results}

\section{Regression Table: 1}

Types of harassment are likely to be related with the age of women employee

$\mathrm{H}_{\mathrm{o}}$ : age has no relation with Types of harassment

$\mathrm{H}_{1}$ : age has a relation with Types of harassment

Variables Entered/ Removed

\begin{tabular}{|l|l|l|l|}
\hline Model & Variables Entered & $\begin{array}{l}\text { Variables } \\
\text { Removed }\end{array}$ & Method \\
\hline 1 & Q1. Age of women employee &. & Enter \\
\hline
\end{tabular}

a. All requested variables entered.

b. Dependent Variable: Q29. Types of harassment

Table: 1.1

\begin{tabular}{|c|c|c|c|c|}
\hline \multicolumn{5}{|c|}{ Model Summary } \\
\hline $\begin{array}{l}\text { Mod } \\
\text { el }\end{array}$ & $\mathrm{R}$ & R Square & $\begin{array}{ll}\text { Adjusted } & \mathrm{R} \\
\text { Square } & \end{array}$ & $\begin{array}{l}\text { Std. Error of } \\
\text { the Estimate }\end{array}$ \\
\hline 1 & $.012^{\mathrm{a}}$ & .000 & -.004 & .979 \\
\hline \multicolumn{4}{|c|}{ a. Predictors: (Constant), Q1 Age of women } & \\
\hline
\end{tabular}


ANOVA $^{s}$

Table No.1.2

\begin{tabular}{|l|l|l|l|l|l|l|}
\hline \multicolumn{2}{|l|}{ Model } & Sum of Squares & df & $\begin{array}{l}\text { Mean } \\
\text { Square }\end{array}$ & F & Sig. \\
\hline \multirow{2}{*}{1} & Regression & .447 & 1 & .447 & 3.80 & $.53^{\text {a }}$ \\
\cline { 2 - 7 } & Residual & 350.469 & 298 & 1.176 & & \\
\cline { 2 - 6 } & Total & 350.917 & 299 & & & \\
\hline $\begin{array}{l}\text { a. Predictors: (Constant), Q1 Age of women } \\
\text { employee }\end{array}$ & & & & \\
\hline \multicolumn{2}{l}{ b. Dependent Variable: Q29.ypes of harassment } & & & & \\
\hline
\end{tabular}

\section{Coefficients}

Table No.1.3

\begin{tabular}{|l|l|c|c|c|c|c|}
\hline \multicolumn{2}{|c|}{ Model } & \multicolumn{2}{|c|}{$\begin{array}{c}\text { Unstandardized } \\
\text { Coefficients }\end{array}$} & $\begin{array}{c}\text { Standardized } \\
\text { Coefficients }\end{array}$ & \multirow{2}{*}{ Sig. } & \\
\cline { 3 - 6 } \multicolumn{2}{|c|}{} & B & Std. Error & Beta & & .000 \\
\hline 1 & (Constant) & 1.061 & .141 & & 7.547 & .000 \\
\cline { 2 - 5 } & $\begin{array}{l}\text { Q1Age of women } \\
\text { employee }\end{array}$ & -2.35 & .056 & -2.35 & 4.19 & .000 \\
\hline
\end{tabular}

a. Dependent Variable:

Q29. Types of harassment

The researcher extracted variables from the questioner to perform the analysis. Two forms of variables are selected, dependent variable and independent variable. As mentioned in Table No.1. Age of women employee is taken as an independent variable and Types of harassment as a dependent variable.

After applying linear regression analysis as shown in Table No.1.1, the model shows significant relationship between variables. The adjusted $\mathrm{R}$ square and the level of significance indicate the relationship.

Whereas in order to confirm the relationship ANOVA test Table No.1.2, is applied to reconfirm the relationship. $\mathrm{P}$-value is 0.000 showing significant relationship.

Table No.13 shows the standard errors of the constant and the coefficients indicating the significance of the model.

By applying the linear regression and ANOVA model, the key findings of this hypothesis is;

1. Type of harassment highly depends upon the age of the women employee.

2. This relationship is negative.

3. The Adjusted R square confirms the validity and reliability of the model. 


\section{Regression Table: 2}

Type of harassment is likely to be related with the Educational qualification of women employee

$\mathrm{H}_{\mathrm{o}}$ : Educational qualification has no relation with type of harassment

$\mathrm{H}_{1}$ : Educational qualification has a relation with type of harassment

\section{Variables Entered/Removed}

\begin{tabular}{|l|l|l|l|}
\hline Model & Variables Entered & Variables Removed & Method \\
\hline 1 & $\begin{array}{l}\text { Q2.Educational } \\
\text { qualification }\end{array}$ & $\cdot$ & Enter \\
\hline
\end{tabular}

a. All requested variables entered.

b. Dependent Variable: Q29.type of harassment

Table No.2.1

Model Summary

\begin{tabular}{|l|l|l|l|l|l|}
\hline Model & $\mathbf{R}$ & R Square & $\begin{array}{l}\text { Adjusted R } \\
\text { Square }\end{array}$ & $\begin{array}{l}\text { Std. Error } \\
\text { of the } \\
\text { Estimate }\end{array}$ & Durbin-Watson \\
\hline 1 & $.412^{\mathrm{a}}$ & .169 & .166 & .893 & .847 \\
\hline
\end{tabular}

Table No.2.2

ANOVA ${ }^{\mathbf{b}}$
\begin{tabular}{|l|l|l|l|l|l|l|}
\hline \multicolumn{2}{|l|}{ Model } & $\begin{array}{l}\text { Sum of } \\
\text { Squares }\end{array}$ & Df & Mean Square & F & Sig. \\
\hline \multirow{2}{*}{1} & Regression & 44.212 & 1 & 44.212 & 55.488 & $.000^{\mathrm{a}}$ \\
\cline { 2 - 8 } & Residual & 216.726 & 272 & .797 & & \\
\cline { 2 - 7 } & Total & 260.938 & 273 & & & \\
\hline
\end{tabular}

a. Predictors: (Constant), Q2 educational qualification

b. Dependent Variable: Q29 type of harassment

\section{Coefficients}

Table No.2.3

\begin{tabular}{|l|l|l|l|l|l|l|}
\hline \multicolumn{2}{|l|}{ Model } & \multicolumn{2}{|l|}{$\begin{array}{l}\text { Un-standardized } \\
\text { Coefficients }\end{array}$} & $\begin{array}{l}\text { Standardized } \\
\text { Coefficients }\end{array}$ & T & Sig. \\
\cline { 3 - 7 } \multicolumn{2}{|l}{} & B & Std. Error & Beta & & \\
\hline 1 & (Constant) & 4.429 & .177 & & 24.993 & .000 \\
\cline { 2 - 8 } & $\begin{array}{l}\text { Q2 educational } \\
\text { qualification }\end{array}$ & -.354 & .048 & -.412 & -7.449 & .000 \\
\hline
\end{tabular}

a. Predictors: (Constant), Q2 educational qualification

b. Dependent Variable: Q29 type of harassment 
The researcher extracted variables from the questioner to perform the analysis. Two forms of variables are selected, dependent variable and independent variable. As mentioned in Table No.2... Educational qualification is taken as an independent variable and Types of harassment as a dependent variable.

After applying linear regression analysis as shown in Table No.2.1 the model shows significant relationship between variables. The adjusted $\mathrm{R}$ square and the level of significance indicate the relationship.

Whereas in order to confirm the relationship ANOVA test Table No.2.2, is applied to reconfirm the relationship. $\mathrm{P}$-value is 0.000 showing significant relationship.

Table No.2.3 shows the standard errors of the constant and the coefficients indicating the significance of the model.

By applying the linear regression and ANOVAs model the key findings of this hypothesis is;

1. Type of harassment highly depends upon Educational qualification of the women employee.

2. This relationship is negative.

3. The Adjusted R square confirms the validity and reliability of the model.

\section{Regression Table: 3}

Types of harassment are likely to be related with the marital status of the women employee.

$\mathrm{H}_{\mathrm{o}}$ : Marital status has no relation with type of harassment at workplaces.

$\mathrm{H}_{1}$ : Marital status has a relation with type of harassment at workplaces.

Table: 3

Variables Entered/Removed

\begin{tabular}{|l|l|c|c|}
\hline Model & Variables Entered & Variables Removed & Method \\
\hline 1 & Q3 Marital status & . & Enter \\
\hline
\end{tabular}

a. All requested variables entered.

b. Dependent Variable: Q29 type of harassment

Table No.3.1

Model Summary

\begin{tabular}{|l|l|l|l|l|l|}
\hline Model & $\mathbf{R}$ & R Square & $\begin{array}{l}\text { Adjusted R } \\
\text { Square }\end{array}$ & $\begin{array}{l}\text { Std. Error of } \\
\text { the Estimate }\end{array}$ & $\begin{array}{l}\text { Durbin- } \\
\text { Watson }\end{array}$ \\
\hline 1 & $.486^{\mathrm{a}}$ & .236 & .234 & .856 & 1.345 \\
\hline
\end{tabular}

a. Predictors: (Constant), Q3 Marital status

b. Dependent Variable: Q29 type of harassment 
ANOVA $^{b}$

Table No.3.2

\begin{tabular}{|l|l|l|l|l|l|c|}
\hline \multicolumn{2}{|l|}{ Model } & Sum of Squares & Df & \multicolumn{1}{|c|}{$\begin{array}{c}\text { Mean } \\
\text { Square }\end{array}$} & F & Sig. \\
\hline \multirow{3}{*}{1} & Regression & 61.664 & 1 & 61.664 & 84.168 & $.000^{\mathrm{a}}$ \\
\cline { 2 - 7 } & Residual & 199.274 & 272 & .733 & & \\
\cline { 2 - 7 } & Total & 260.938 & 273 & & & \\
\hline
\end{tabular}

a. Predictors: (Constant), Q3 Marital status

b. Dependent Variable: Q29 type of harassment

Table No.3.3

Coefficients

\begin{tabular}{|l|l|l|l|l|l|l|}
\hline \multirow{2}{*}{ Model } & \multicolumn{2}{|l|}{$\begin{array}{l}\text { Un-standardized } \\
\text { Coefficients }\end{array}$} & $\begin{array}{l}\text { Standardized } \\
\text { Coefficients }\end{array}$ & \multirow{2}{*}{ Sig. } \\
\cline { 3 - 5 } \multicolumn{2}{l|}{} & B & Std. Error & Beta & & \\
\hline \multirow{2}{*}{1} & (Constant) & -.278 & .379 & & -.731 & .465 \\
\cline { 2 - 7 } & Q3 marital status & -.724 & .079 & -.486 & -9.174 & .000 \\
\hline
\end{tabular}

a. Dependent Variable: Q29 type of harassment

The researcher extracted variables from the questioner to perform the analysis. Two forms of variables are selected, dependent variable and independent variable. As mentioned in Table No.3., Marital status of the women employee is taken as an independent variable and Types of harassment as a dependent variable.

After applying linear regression analysis as shown in Table No.3.1 the model shows significant relationship between variables. The adjusted $\mathrm{R}$ square and the level of significance indicate the relationship.

Whereas in order to confirm the relationship ANOVA test Table No.3.2 is applied to reconfirm the relationship. $\mathrm{P}$-value is 0.000 showing significant relationship.

Table No.3.3 shows the standard errors of the constant and the coefficients indicating the significance of the model.

By applying the linear regression and ANOVA model the key findings of this hypothesis is;

1. Type of harassment highly depends upon the marital status of the women employee.

2. This relationship is negative.

3. The Adjusted R square confirms the validity and reliability of the model. 


\section{Regression Table: 4}

Types of harassment are likely to be related with the physical attractiveness of the women employee.

$\mathrm{H}_{\mathrm{o}}$ : Physical attractiveness of the women has no relation with type of harassment.

$\mathrm{H}_{1}$ : Physical attractiveness of the women has a relation with type of harassment.

Table:4

Variables Entered/Removed

\begin{tabular}{|l|c|c|c|}
\hline Model & Variables Entered & Variables Removed & Method \\
\hline 1 & $\begin{array}{c}\text { Q21 physical } \\
\text { attractiveness }\end{array}$ & & Enter \\
\hline
\end{tabular}

a. All requested variables entered.

b. Dependent Variable: Q29 type of harassment

Table No.4.1

Model Summary

\begin{tabular}{|l|c|c|c|c|}
\hline Model & R & R Square & $\begin{array}{c}\text { Adjusted R } \\
\text { Square }\end{array}$ & $\begin{array}{c}\text { Std. Error of the } \\
\text { Estimate }\end{array}$ \\
\hline 1 & $.805^{\mathrm{a}}$ & .647 & .644 & .569 \\
\hline
\end{tabular}

a. Predictors: (Constant)

\begin{tabular}{|l|l|c|c|c|c|c|}
\hline \multicolumn{2}{|l|}{ Model } & Sum of Squares & Df & Mean Square & F & Sig. \\
\hline \multirow{3}{*}{1} & Regression & 67.833 & 1 & 67.833 & 209.274 & $.000^{\text {a }}$ \\
\cline { 2 - 7 } & Residual & 36.951 & 114 & .324 & & \\
\cline { 2 - 7 } & Total & 104.784 & 115 & & & \\
\hline
\end{tabular}

a. Predictors: (Constant), Q21

b. Dependent Variable:Q29 type of harassment

Table No. 4.3

Coefficients

\begin{tabular}{|l|l|c|c|c|c|c|}
\hline \multicolumn{2}{|l|}{ Model } & \multicolumn{2}{|c|}{$\begin{array}{c}\text { Un-standardized } \\
\text { Coefficients }\end{array}$} & $\begin{array}{c}\text { Standardized } \\
\text { Coefficients }\end{array}$ & \multirow{2}{*}{ T } & \multirow{2}{*}{ Sig. } \\
\cline { 3 - 7 } \multicolumn{2}{|l}{} & B & Std. Error & Beta & & \\
\hline \multirow{2}{*}{1} & (Constant) & 3.459 & .087 & & 39.701 & .000 \\
\cline { 2 - 7 } & $\begin{array}{l}\text { Q21 physical } \\
\text { attractiveness }\end{array}$ & -.434 & .030 & -.805 & -14.466 & .000 \\
\hline
\end{tabular}

a. Dependent Variable

Q29 type of harassment

The researcher extracted variables from the questioner to perform the analysis. Two forms of variables are selected, dependent variable and independent variable. As 
mentioned in Table No.4. Physical attractiveness of the women employee is taken as an independent variable and Types of harassment as a dependent variable.

After applying linear regression analysis as shown in Table No.4.1 the model shows significant relationship between variables. The adjusted $\mathrm{R}$ square and the level of significance indicate the relationship.

Whereas in order to confirm the relationship ANOVA test Table No.4.2 is applied to reconfirm the relationship. $\mathrm{P}$-value is 0.000 showing significant relationship.

Table No.4.3 shows the standard errors of the constant and the coefficients indicating the significance of the model.

By applying the linear regression and ANOVA model, the key findings of this hypothesis is;

1. Type of harassment highly depends upon the physical attractiveness of the women employee.

2. This relationship is negative.

3. The Adjusted R square confirms the validity and reliability of the model.

\section{Regression Table \# 5}

Types of harassment are likely to be related with working environments of an organization.

$\mathrm{H}_{\mathrm{o}}$ : working environments of an organization has no relation with type of harassment.

$\mathrm{H}_{1}$ : working environments of an organization has a relation with type of harassment.

Table: 5

Variables Entered/Removed

\begin{tabular}{|l|c|c|c|}
\hline Model & Variables Entered & Variables Removed & Method \\
\hline 1 & $\begin{array}{r}\text { Q19working } \\
\text { environment }\end{array}$ & & Enter \\
\hline
\end{tabular}

a. All requested variables entered.

b. Dependent Variable:

Q29 type of harassment

Table No.5.1

Model Summary

\begin{tabular}{|l|c|c|c|c|}
\hline Model & R & R Square & $\begin{array}{c}\text { Adjusted R } \\
\text { Square }\end{array}$ & $\begin{array}{c}\text { Std. Error of } \\
\text { the Estimate }\end{array}$ \\
\hline 1 & $.053^{\mathrm{a}}$ & .003 & .000 & .978 \\
\hline
\end{tabular}

a. Predictors: (Constant) 
ANOVA $^{\text {b }}$

Table: 5.2

\begin{tabular}{|l|l|l|l|l|l|l|}
\hline \multicolumn{2}{|l|}{ Model } & $\begin{array}{l}\text { Sum of } \\
\text { Squares }\end{array}$ & Df & Mean Square & F & Sig. \\
\hline \multirow{3}{*}{1} & Regression & .734 & 1 & .734 & .767 & $.382^{\mathrm{a}}$ \\
\cline { 2 - 8 } & Residual & 260.204 & 272 & .957 & & \\
\cline { 2 - 7 } & Total & 260.938 & 273 & & & \\
\hline
\end{tabular}

a. Predictors: (Constant), Q19

b. Dependent Variable:

Q29 type of harassment

Table: 5.3

Coefficients

\begin{tabular}{|l|l|c|c|c|c|c|}
\hline \multicolumn{2}{|l|}{ Model } & \multicolumn{2}{|c|}{$\begin{array}{c}\text { Un-standardized } \\
\text { Coefficients }\end{array}$} & $\begin{array}{c}\text { Standardized } \\
\text { Coefficients }\end{array}$ & T & Sig. \\
\cline { 3 - 5 } & B & Std. Error & Beta & & \\
\hline 1 & (Constant) & 2.312 & .983 & & 2.353 & .019 \\
\cline { 2 - 6 } & $\begin{array}{l}\text { Q19 working } \\
\text { environment }\end{array}$ & .173 & .198 & .053 & .876 & .382 \\
\hline
\end{tabular}

Q29 type of harassment

The researcher extracted variables from the questioner to perform the analysis. Two forms of variables are selected, dependent variable and independent variable. As mentioned in Table No.5. Working environments of an organization is taken as an independent variable and Types of harassment as a dependent variable.

After applying linear regression analysis as shown in Table No.5.1 the model shows significant relationship between variables. The adjusted $\mathrm{R}$ square and the level of significance indicate the relationship.

Whereas in order to confirm the relationship ANOVA test Table No.5.2 is applied to reconfirm the relationship's-value is showing significant relationship.

Table No.5.3 shows the standard errors of the constant and the coefficients indicating the significance of the model.

By applying the linear regression and ANOVA model, the key findings of this hypothesis is;

1. Type of harassment highly depends upon the working environments of an organization.

2. This relationship is positive. 
3. The Adjusted R square confirms the validity and reliability of the model.

\section{Regression Table \# 6}

Types of harassment are likely to be related with the positions of women employee.

$\mathrm{H}_{\mathrm{o}}$ : A position of women employee has no relation with type of harassment.

$\mathrm{H}_{1}$ : A position of women employee has a relation with type of harassment.

Table: 6

Variables Entered/Removed

\begin{tabular}{|l|c|c|c|}
\hline Model & Variables Entered & Variables Removed & Method \\
\hline 1 & $\begin{array}{c}\text { Q14 positions of } \\
\text { women }\end{array}$ & & Enter \\
\hline
\end{tabular}

a. All requested variables entered.

b. Dependent Variable: Q29 type of harassment

Table: 1

Model Summary

\begin{tabular}{|l|c|c|c|c|}
\hline Model & R & R Square & $\begin{array}{c}\text { Adjusted R } \\
\text { Square }\end{array}$ & $\begin{array}{c}\text { Std. Error of the } \\
\text { Estimate }\end{array}$ \\
\hline 1 & $.224^{\mathrm{a}}$ & .050 & .047 & .955 \\
\hline
\end{tabular}

a. Predictors: (Constant)

Table No.6.2

ANOVA $^{b}$

\begin{tabular}{|l|l|c|c|c|c|c|}
\hline \multicolumn{2}{|l|}{ Model } & $\begin{array}{c}\text { Sum of } \\
\text { Squares }\end{array}$ & Df & Mean Square & F & Sig. \\
\hline \multirow{2}{*}{1} & Regression & 13.118 & 1 & 13.118 & 14.398 & $.000^{\mathrm{a}}$ \\
\cline { 2 - 7 } & Residual & 247.820 & 272 & .911 & & \\
\cline { 2 - 7 } & Total & 260.938 & 273 & & & \\
\hline
\end{tabular}

a. Predictors: (Constant),

b. Dependent Variable:

Q29 type of harassment

Table No.6.3

\begin{tabular}{|l|l|l|l|l|l|l|}
\hline \multicolumn{2}{|l|}{ Model } & \multicolumn{2}{|l|}{$\begin{array}{l}\text { Un-standardized } \\
\text { Coefficients }\end{array}$} & $\begin{array}{l}\text { Standardized } \\
\text { Coefficients }\end{array}$ & T & Sig. \\
\cline { 3 - 7 } \multicolumn{2}{l|}{} & B & Std. Error & Beta & & \\
\hline \multirow{2}{*}{1} & (Constant) & 4.089 & .248 & & 16.455 & .000 \\
\cline { 2 - 6 } & $\begin{array}{l}\text { Q14 positions } \\
\text { of women }\end{array}$ & -.326 & .086 & -.224 & -3.795 & .000 \\
\hline
\end{tabular}

a. Dependent Variable:

Q29 type of harassment 
The researcher extracted variables from the questioner to perform the analysis. Two forms of variables are selected, dependent variable and independent variable. As mentioned in Table No.6. Positions of women employee is taken as an independent variable and Types of harassment as a dependent variable.

After applying linear regression analysis as shown in Table No.6.1 the model shows significant relationship between variables. The adjusted $\mathrm{R}$ square and the level of significance indicate the relationship.

Whereas in order to confirm the relationship ANOVA test Table No.6.2 is applied to reconfirm the relationship. $\mathrm{P}$-value is 0.000 showing significant relationship.

Table No.6.3 shows the standard errors of the constant and the coefficients indicating the significance of the model.

By applying the linear regression and ANOVA model the key findings of this hypothesis is;

1. Type of harassment highly depends upon the positions of women employee.

2. This relationship is negative.

3. The Adjusted R square confirms the validity and reliability of the model.

\section{Findings}

The researcher has found that $24 \%$ of respondent belongs to age 20 - Below, $49 \%$ belong to 21-30 years of age, $22 \%$ of respondents belong to $30-39$ age group and only 5\% belong to 41-Above years of age. Mostly $47 \%$ of respondents were intermediate and $63 \%$ of the respondents belong to nuclear family $\mathrm{d}$ mostly.

It was found that mostly $49 \%$ respondents were married, and mostly $43 \%$ have Rs. 20,001 - 25,000 family income while 40\% respondents have 10,001 - 15,000, personal income, It was found that structure of organization is $41 \%$ Gender based hierarchical structure, $9 \%$ Sex segregation of job and $50 \%$ sex ratio within the job while $49 \%$ of the respondents are temporary workers yet and $51 \%$ are permanent.

It was found that responsibility of respondents at workplace to be $88 \%$ in packaging, while $88 \%$ respondents avail overtime due to order of boss, $13 \%$ colleague request. The environment of their organization to be mostly $65 \%$ informal and the kind of demand to be $12 \%$ to spend some time, $7 \%$ offer tea, $67 \%$ for late sitting. It was found that, majority $88 \%$ respondents are threatened for termination if demand is not fulfilled.

It was found that $7 \%$ are harassed by manager, $56 \%$ by supervisor, and $33 \%$ by colleague, $2 \%$ client and $2 \%$ customers. While the kind of harassment to be mostly $52 \%$ verbal. It 
was found that in sexual harassment $50 \%$ respondents out of 2 suffer from attempt to rape and $50 \%$ suffer from assault.

\section{Conclusions}

Present study reveals that age, education, marital status, family background and job status/position, working environment all are significantly affecting cause of women harassment at work place and kind of women harassment at workplace. Study also descriptively analyzes the close relationship found in workers integration. Although laws and legal protection is been provided to the victims but due to improper implementation of laws and rights women feel unsafe to report on such incidents. Social structure of society also engraves the situation and restricts women to report or even raise a voice over these unlawful unethical acts. Before the action is based primarily on sex discrimination, it became recognized as sexual harassment. Sexual harassment in the name of the employer, political relations have developed considerably over time, to create responsibility. Applications must be submitted to reinforce sexual harassment increased. In recent years, we have the right opportunity to appeal to the Commission on Equal (EEOC) and improve evaluation to clarify the allegations of sexual abuse, the treatment of cases of sexual harassment, and others.

\section{Recommendations}

- The Government should implement existing laws to prevent women's harassment and convicts employers who are encouraging the conditions.

- The government should modify legislate empowered labor laws which ensure equal pay to equal work.

- Law enforcement must be improved and vigilant. Government must empower labor officers to maintain proper professional environment and no harassment should be done on any grounds.

- The government should impose financial penalties and short term convictions on discrimination of women against the inducting process and make sure there must be no legal or technical barrier of women entering or leaving any profession.

- Government should encourage, support the development programs of women and give incentive to the employer who is investing in human capital of their workforce.

- It is government's responsibility to aware and educates people about gender discrimination and harassment .government should run and support public awareness programs.

- The government should conduct and support researches on women harassment and gender discrimination to get better understanding of the issue and eradicate it. 
- Ministry of human rights must have powers to review the existing laws evaluate and customize it to the basic needs. Prompt action against sexual harassment can discourage other potential prospects.

- The government should established administrative body to examine harassment complaints and have second tier of checks and balance.

- Employee should implement sexual harassment policy at work place.

\section{References}

Berdahl, Jennifer L.; Moore, Celia, (Mar 2006). Workplace Harassment: Double Jeopardy for Minority Women "Journal of Applied Psychology, vol. 91 (2)". http://dx.doi.org/10.1037/0021-9010.91.2.426

Chappell, D., Martino, V. D., \& I. L. (2006). Violence at Work (Third ed.). Geneva: International Labour Office.

Cleveland, J. N., \& Kerst, M. E. (1993). Sexual Harassment and Perceptions of Power; an Under Articulated Relationship, Journal of Vocational Behavior.

Dawn Newspaper. (2010, December 21). Six booked for harassing female teacher. Retrieved from Dawn Newspaper: Dawn Newspaper. (2011, April 2.Dawn Newspaper. (2012, May 18)

Federal Communications Commission Staff. (2011, May 1). Understanding Workplace Harassment (FCC Staff). Retrieved from Federal Communications Commission: http://www.fcc.gov/encyclopedia/understanding-workplace-harassment-fcc-staff

Fitzgerald, L., M. Gelfand and F. Drasgow (1995), "Measuring sexual harassment: Theoretical and psychometric advances", Basic and Applied Social Psychology, vol. 17 (4) http://vaw.sagepub.com/content/6/2/118.abstract

Gutek, B. A., \& Morasch, B. (1982). Sex Ratios, Sex role spill over, and Sexual Harassment of Women at work. Journal of Social issues.http://www.jstor.org/discover/10.2307/256581?sid=21105153120401\&uid $=2 \&$ uid $=2129 \&$ uid $=3738832 \&$ uid $=70 \&$ uid $=4$

Gutek, B. and A. Cohen (1987), "Sex ratios, sex role spillover, and sex at work: A comparison of men's and women's experiences", Human Relations, vol. 40 (2) http://hum.sagepub.com/content/40/2/97.refs 
Hausen, M. (2010, November 26). Sexual harassment: No means no. Retrieved from The Express Tribune: http://tribune.com.pk/story/81781/

Hurt, J. L. (2000), "Why Harassment Happens At Work: Theoretical Developments of the Antecedents of Sexual Harassment", in Department of Psychology, (eds) Purdue University.

Journalism Pakistan. (2010, October 27). Sexual harassment bane of female journalists. Retrieved from Journalism Pakistan: http://www.journalismpakistan.com/newsdetail.php?newsid=52

Lach, D. H., \& Gwartney-Gibbs, P. A. (1993). Sociological perceptive on sexual harassment and workplace dispute resolution. Journal of Vocational Behavior.http://citation.allacademic.com/meta/p_mla_apa_research_citation/1/0/3 /1/1/pages103114/p103114-26.php

M. A. Johnson, \& J.D, HR (2003). Introduction to Harassment Prevention. Chicago: Catherine Wolfe.

NW, United States : Harassment in the Workplace. CRC Press.

Optotow, S. (1990). Moral Exclusion and Injustice: An overview, Journal of Social Issues.

P. S. (n.d.). In Pakistan Majority of women suffer harassment at workplace. Retrieved from Pak Study: http://pakstudy.com/web/node/4511

R. Siegel (2004). A Short History of Sexual Harassment. In Directions in Sexual Harassment Law (p. 3). Yale University Press.

Saeed, Fouzia (2012). Working with sharks: Lahore: Sanjh Publishers.

Sarandakos Sotirious (1993) Social Research, Australia, MacMillan Education.

Stud, M. V., \& Gattiker, U.E. (1991). The Evolutionary psychology of sexual harassment in organizations, Ettology and Sociobiology. http://www.borjournals.com/a/ index.php/jbmssr/article/view/208

Tangri, S., M. Burt and L. Johnson (1982). "Sexual harassment at work: Three explanatory models", Journal of Social Issues, vol. 38 (4) http://jrc.sagepub.com/content/37/3/306.abstract 
The University of British Columbia. (n.d.). Impact and Consequences. Retrieved February 17, 2011, from The University of British Columbia: http://www.ubc.ca/ okanagan/equity/discrimination/impact.html

U. W. (2009, May 31). PAKISTAN: Policy guidelines on sexual harassment. Retrieved from University World News: http://www.universityworldnews.com/article.php? story $=20090528170702253$

U.S Equal Employment Opportunity Commission. (1990, 3 19). Current Issues. Retrieved from U.S Equal Employment Opportunity Commission: http://www.eeoc.gov/policy/docs/currentissues.html

United Nations Declaration on Elimination of Violence against Women. (1993). Human Rights. Retrieved from United Nations Population Fund: http://www.unfpa.org/rights/violence.htm

Vaux, A. (1993). Paradigmatic Assumptions in Sexual Harassment Research: Being guided without being mislead. Journal of vocational Behavior. http://www.sciencedirect.com/science/article/pii/S0001879183710080

Wasim, A. (n.d.). Zardari signs bill: Harassment of women is now a crime. Retrieved from Dawn Newspaper: http://archives.dawn.com/archives/32680

Yeti. (2011, October 21). Pakistan: Sexual harassment faced by minorities. Retrieved from Pakistan Defence: http://www.defence.pk/forums/social-issues-currentevents/136083-pakistan-sexual-harassment-faced-minorities.html

Dr. Rana Saba Sultan is Professor in the Department of Sociology, University of Karachi.

Dr. Ambreen Akbar is Assistant Professor in the Department of Media Communication, Sindh Madarsa-tul-Islam University, Karachi.

Nargis Ahmed is Visiting Professor in the Department of Sociology, Jinnah University for Women, Karachi.

Mussarat Parveen is Ph.D Research Scholar in the Department of Sociology, University of Karachi. 